Він вважав, що «за самою своєю логікою, за філософською основою, за творчим характером педагогічна праця неможлива без елемента дослідження і насамперед тому, що кожна людська індивідуальність, 3 якою ми маємо справу, це певною мірою своєрідний, неповторний світ думок, почуттів, інтересів». «У самій своїй основі педагогічна праця - справжня творча праця - стоїть близько до наукового дослідження» [7, с. 471-472]. Тому впродовж своєї управлінської діяльності директор Павлиської середньої школи плекав із кожного вчителя дослідника-практика 3 педагогіки і психології.

В. О. Сухомлинський власною науковою і практичною діяльністю на посаді директора сільської школи, яка стала світовою лабораторією інноваційного використання педагогіки і психології, залишив актуальну пораду своїм колегам - директорам закладів загальної середньої освіти Нової української школи: «Уміння керувати колективом залежить від того, наскільки глибоко розуміє керівник найтонші деталі педагогічного процесу, його глибинні джерела духовний світ школяра, особливості його розумової праці, процес опанування знань, формування переконань. Директор школи повинен бути знаючим, досвідченим педагогом і психологом» [7, с. 395].

Висновки. Психолого-педагогічна спадщина В. О. Сухомлинського досить багатоаспектна, іiї пронизує проблема проєктування людини, яка грунтується на ідеї всебічного розвитку особистості. Ця ідея залишається актуальною і сьогодні. Він мріяв, щоб кожен педагог був не просто «споживачем» педагогічних і психологічних знань, а дослідником і раціоналізатором, творцем. Саме цього вимагає від нас час, саме такі завдання ставлять перед нами учні нової української школи, саме такі можливості відкриває перед нами реформування освіти.

Із метою реалізації завдань нової української школи в контексті новаторського досвіду В. О. Сухомлинського вдосконалення потребує педагогічна і психологічна підготовка вчителів як активних суб'єктів освітніх нововведень через неперервну післядипломну освіту.
Оскільки вона, по-перше, відповідає потребам і закономірностям еволюції інформаційного суспільства та $є$ фактором розвитку й постійного забезпечення психолого-педагогічної культури вчителя, а по-друге, адекватна специфіці освітньої діяльності, ролі та місцю особистості вчителя-інноватора в освітньому процесі, що передбачає безперервне збагачення його професійної компетентності.

\section{СПИСОК ВИКОРИСТАНОЇ ЛІТЕРАТУРИ}

1. Концепція «Нова українська школа» [Електронний ресурс] / Міністерство освіти і науки України. URL: https://mon.gov.ua/storage/app/media/zagalna\%20 serednya/nova-ukrainska-shkola-compressed.pdf (дата звернення: 18.06.2019).

2. Луцюк А. М. Василь Сухомлинський про педагогічну майстерність учителя (до 100-річчя 3 дня народження) : монографія / А. М. Луцюк. - Вид. 2-е, виправ. та доповн. - Луцьк : Вежа-Друк, 2018. - 176 с.

3. Спадщина В. О. Сухомлинського - джерело сучасної педагогічної практики : монографія / авт. кол. : В. О. Сухомлинська, О. Я. Савченко, П. С. Олешко, А. М. Луцюк та ін., упор. П. С. Олешко. - Луцьк : Надстир'я, 2016. - 256 с.

4. Сухомлинський В. О. Наша «скрипка» [Текст] / В. О. Сухомлинський // Рад. освіта. - 1966. -21 травня.

5. Сухомлинський В. О. Методика виховання колективу / В. О. Сухомлинський // Вибр. твори : в 5 т. K., 1976 - 1977. - T. 1. - C. 403-637.

6. Сухомлинський В. О. Павлиська середня школа [Текст] / В. О. Сухомлинський // Вибр. твори : в 5 т. Т. 4. - К. : Рад. шк., 1977. - С. 7-390.

7. Сухомлинський В. О. Розмова з молодим директором / В. О. Сухомлинський // Вибрані твори : в 5-ти т. - Т. 4. - К. : Рідна школа, 1976. - С. 393-626.

8. Сухомлинський В. О. Як виховати справжню людину [Текст] / В. О. Сухомлинський // Вибр. твори : в 5 т. - Т. 2. - К. : Рад. шк., 1976. - С. 149-416.

Дата надходження до редакиії: 09.07.2019 p.

\title{
ПРОЦЕС ФОРМУВАННЯ ОСОБИСТОСТІ ДИТИНИ $З$ ОСОБЛИВИМИ ОСВІТНІМИ ПОТРЕБАМИ НА ОСНОВІ ПЕДАГОГІЧНОГО ДИЗАЙНУ В. О. СУХОМЛИНСЬКОГО
}

У статті висвітлено питання формування особистості дитини з особливими освітніми потребами на основі педагогічного дизайну В. О. Сухомлинського. Відображено умови родинного виховання та проаналізовано їх важливий вплив на дітей.
Обтрунтовано необхідність професійного розвитку сучасного педагога до побудови інклюзивного простору.

Ключові слова: інклюзивна освіта, діти з особливими освітніми потребами, сімейне виховання, психофізичний розвиток. 
B cmaтье раскрыты вопросы формирования личности ребенка с особенными образовательными потребностями на основе педагогического дизайна В. А. Сухомлинского. Отражень условия семейного воспитания и проанализировано их важное влияние на детей. Обосновано необходимость профессионального развития современного педагога к преобразованию инклюзивного пространства.

Ключевые слова: инклюзивное образование, дети с особенными образовательными потребностями, семейное воспитание, психофизическое развитие.

The article deals with the issues of peculiarities of personality formation of a child with special educational needs, reflects the conditions of family upbringing and analyzes the importance of their influence on children. The necessity of professional development of a modern teacher to construct an inclusive space is substantiated. According to the title, the article deals with the peculiarities of working with children with special educational needs in the conditions of inclusive education, humane treatment of them and promoting their adaptation in society.

Particularly noteworthy is the importance of pedagogical interaction between teachers and parents of children in the context of the New Ukrainian School. The importance of modern research on working with children with special educational needs is mentioned in the article. Basic information about «special» children and recommendations in the state documents of Ukraine «On Education" are provided. The text provides valuable information on the practical use of pedagogical research teacher V. Sukhomlinsky on ways to overcome difficulties in teaching children.

This article will be of use to teachers, psychologists, scientists and is of interest to the work of Inclusive Resource Centers and Educational Institutions. The article gives a detailed analysis of the peculiarities and tasks of family education of children with special educational needs. Particular attention is paid to the psychological level of perception of the child with the problems of the parents. The proposed article materials will be useful in practical use in educational institutions, will facilitate the organization of active work with parents of children.

Key words: inclusive education, children with special educational needs, family education, psychophysical development.

Постановка проблеми. За останні десятиліття в Україні збільшилася кількість дітей з особливими освітніми потребами, які заслуговують посиленої уваги з боку родини і держави. Зважаючи на це, важливого значення набувають умови формування життєвих навичок в «особливих» дітей, їх адаптування до реалій життя. Адже вагомим показником розвитку суспільства $\epsilon$ гуманне, турботливе й милосердне ставлення до дітей із особливими потребами, а також сприяння їм у повноцінному житті.

Метою статті $\epsilon$ висвітлення теоретичних і практичних підходів до обгрунтування важливості педагогічної взаємодії вчителів з батьківською спільнотою стосовно роботи 3 дітьми 3 особливими освітніми потребами, усвідомлення важливості самоосвіти та використання ідей педагога-гуманіста, мислителя та новатора В. О. Сухомлинського в упровадженні ідей Нової української школи.
Аналіз наукових досліджень та публікацій. У період реформування освіти одним із найбільш актуальних питань $є$ забезпечення рівного доступу до навчання дітей $з$ особливими освітніми потребами. Особливості інклюзивної освіти розглядали у своїх дослідженнях такі науковці, як В. Бондар, В. Засенко, А. Колупаєва, О. Таранченко, Т. Сак та ін. Вивченням особливостей психологічної підтримки, виховних впливів, гуманістичного спрямування освіти дітей займалися Л. Виготський, В. Громовий, Л. Занков, В. Сухомлинський та ін.

Виклад основного матеріалу. Ідея інклюзії, що виникла як усвідомлення цінності людської багатоманітності і відмінностей між людьми, виключає будь-яку дискримінацію та відображає одну з головних ознак демократичного суспільства: всі діти є цінними членами суспільства і мають рівні права, зокрема щодо отримання освіти, незважаючи на особливості їхнього психофізичного розвитку. Діти, які потребують інклюзивної освіти, можуть не мати інвалідності, але вони мають особливі освітні потреби. Згідно із Законом України «Про освіту» дитина з особливими освітніми потребами (далі - ООП) - «це особа, яка потребує додаткової постійної чи тимчасової підтримки в освітньому процесі з метою забезпечення ії права на освіту» [5, с. 11].

ЮНЕСКО розглядає особливі освітні потреби як досить широке поняття та до категорії дітей з ООП відносить дітей, які мають такі порушення в розвитку: емоційні й поведінкові, мовлення та спілкування, труднощі в навчанні, затримка / обмеження інтелектуального розвитку, фізичні / нейромоторні, а також зору і слуху. Цей список доповнюють діти, які виховуються в несприятливому середовищі: діти, що належать до груп етнічних меншин; діти вулиці та діти, хворі на ВІЛ-інфекцію / СНІД [5, с. 12].

Варто зауважити, що інклюзивна освіта не ставить собі за мету зробити всіх однаковими, а передбачає створення рівних можливостей для всіх дітей 3 ООП і забезпечення їх успіху в освітньому процесі та подальшому житті.

Особливі потреби - це термін, який використовується щодо осіб, чия соціальна, фізична або емоційна особливість потребує спеціальної уваги і послуг, яким надається можливість розвинути свій потенціал, зокрема й освітній. Отже, розвиток дитини з ООП - це взаємопов'язаний процес безперервних кількісних і якісних змін у біологічній, психічній, соціальній та духовній (моральній) сферах, ключовими факторами яких є процес навчання та виховання» [5, с. 82-84].

Сьогодні зміни в освіті передбачають становлення нової сучасної особистості з притаманними їй рисами: спрямованістю на навчання впродовж життя, комунікативністю, умінням об'єднуватися та працювати колективно, вміннями критично мислити та бути креативними. Упродовж останніх років, зважаючи на впровадження інклюзивного навчання, що передбачає залучення батьків як активних учасників освітнього процесу, в теорії та практиці педагогічної науки виникла необхідність активного вивчення сім'ї, яка виховує дитину з особливими потребами. Фахівців цікавлять питання не лише формування в дітей нових умінь та навичок, вони розглядають сім'ю як основний стабілізуючий фактор адаптації дитини. Саме $з$ власної сім’ї дитина виносить у доросле життя перші уявлення про морально-людські цінності, норми поведінки, характер взаємовідносин між людьми. У сім’ї діти не лише наслідують близьких, а й орієнтуються на їхні соціальні та моральні установки. 
Не завжди умови виховання в сучасній сім'ї, на жаль, є сприятливими для розвитку і виховання неповносправних дітей. Окрім того, виховання неповноцінної дитини особливо складне та відповідальне. Цю відповідальність батьки зобов'язані нести перед своєю дитиною та суспільством усе життя.

У контексті означеного вище важливими є здобутки В. Сухомлинського, який наголошував, що питання про «важких» дітей - одна із найскладніших проблем виховання, за байдуже ставлення до якої доводиться розплачуватися дорогою ціною. У своїх працях «Важкі діти», «Вірте в людину», «Розмова 3 молодим директором школи», «Мудра влада колективу», «Серце віддаю дітям», «Батьківська педагогіка» тощо він усебічно аналізував причини, з якими пов'язана поява важких дітей.

Сучасною $є$ думка вченого про навчання дітей $з$ особливими потребами в масовій загальноосвітній школі та їх перебування в атмосфері повноцінного духовного життя закладу. Василь Сухомлинський постійно звертає увагу на індивідуалізацію роботи 3 такими дітьми, оскільки вбачає конкретну роботу педагога у визначенні причини проблеми в кожному окремому випадку, необхідності знайти кожній дитині посильну розумову працю, знаходженні шляхів подолання труднощів, інтелектуальному розвитку, який базується на основі почуття власної гідності. На думку Василя Олександровича, гармонійний і всебічний розвиток особистості можливий лише за умови, де тісно співпрацюють два вихователі - школа і сім'я. Саме спільні дії, висування однакових вимог, дотримання єдиних принципів, чіткі погляди на цілі, методи і засоби виховання стають виховним середовищем для спілкування і спільної діяльності, додають радості та впевненості дитині.

Переглядаючи педагогічні напрацювання В. Сухомлинського «Тайники перевантаження», «Проти перевантаження», «I ліс, і кожне дерево», «Чому дітям важко вчитися», «Парадокси навчання», «Всемогуча радість пізнання», «Без казки не можна уявити дитинство», знаходимо рекомендації вчителям про дотримання дидактичних принципів доступності, посильності навчання, врахування положення Л. С. Виготського про те, що навчання має йти попереду розвитку учня.

Досить актуальною є думка великого педагога про природу дитячого мислення, щоб знання були не лише метою, а й засобом, інструментом, за допомогою якого здобуваються нові знання. Саме у статті «Чому дітям важко вчитися» В. О. Сухомлинський стверджує, що тільки тоді, коли знання, які викладаються вчителем, не відриватимуться від першоджерела - від чуттєвого досвіду дітей (відчуттів, сприймань, уявлень), вони стануть справжніми знаннями.

Основне напрацювання мудрого вчителя з Павлиша, який упродовж 35 років працював в одній сільській школі, спостерігав за життям не лише успішних, але й знедолених дітей, аналізував, мислив, робив висновки і залишив нам у спадок свій неоціненний досвід полягає у проведеному лонгітюдному дослідженні [2; 3].

Лонгітюдність дослідження В. Сухомлинського має переконливі аргументи:

1) термін роботи в одній школі (Павлиській) упродовж 35 років;
2) можливість дослідження спадкового фактора прояву розумових здібностей та інтелектуальної праці не лише в дітей, а й у батьків;

3) експеримент фактично здійснювався у звичайних умовах освітнього процесу.

Дослідник виявив первинні та вторинні причини проблем у дітей: первинними причинами нерідко були хвороби, перенесені в ранньому дитинстві (ревматизм, рахіт, менінгіт та ін.), неякісне харчування, алкоголізм батьків. Та в багатьох випадках первинна причина не призвела б до згубних результатів, якби не з'явилася вторинна - неправильне виховання в ранньому дитинстві буквально від того дня, коли дитина вперше відкрила очі на світ і вперше вступила до школи. Бувало і так, що неправильне виховання в дитинстві - єдина причина пониженої, ослабленої пам'яті, неповноцінної функціональної діяльності мозку. У таких випадках розумові здібності були не кращі, ніж у тих сім'ях, де до неправильного виховання приєднувалися хвороби чи неякісне харчування [3, с. 249-250].

Особливості навчання таких дітей у школі залежать від батьків та суспільства. Наголосимо на оптимістичному баченні долі цих дітей В. О. Сухомлинським: «І все ж вони не є приреченими людьми. Я переконаний, що вчити і виховувати їх належить саме в нормальній школі. Я б назвав цих дітей тендітними і ніжними квітками в безмежно розмаїтому квітнику людства... Гуманну місію вихователя я бачив і бачу в тім, щоб рятувати цих дітей, уводити їх у світ суспільства, духовного життя, краси цілком повноцінними і щасливими» [3, с. 244].

Зважаючи на означене вище, можемо зробити висновок, що дитина з особливими потребами, яка позбавлена правильного виховання, буде мати особистісний недорозвиток та може стати тягарем для родини і суспільства.

Сім'я дитини з відхиленнями в розвитку є іiї першим соціалізуючим інститутом. Процес дорослішання дітей такої категорії відбувається зі значними труднощами та в дещо сповільненому темпі [1, с. 56-65]

Усі ці процеси неможливі без активної діяльності соціальних та психологічних, інклюзивних служб (районних, міських, шкільних). Однак роботу iз сім'ями дітей з особливими потребами неможливо чітко організувати без усебічного вивчення проблем сім'ї, родинно-дитячих відносин.

Кожна дитина має свої слабкі та сильні сторони і проходить індивідуальний шлях розвитку. У процесі виховання дітей із психофізичними порушеннями необхідно враховувати об'єктивні труднощі їхнього розвитку, а саме: труднощі мовленнєвої комунікації, соціальну інфантильність, несформованість соціально-побутової компетентності, емоційного розвитку, порушення поведінки, нечіткі уявлення про систему поведінки, порушення загального психічного розвитку та ін.

Відхилення в розвитку особистості дитини виявляються по-різному: в неконкретному розумінні мотивів діяльності, в обмеженні знань про вимоги колективу або ж у невмінні зіставляти свої наміри, бажання із загальними цілями. У дітей із вадами слуху проблеми формуються у сфері словесно-логічного мислення. Порушення слухових сприймань викликає підозріливість, неможливість зрозуміти почуте. 
Це призводить до нестійкої поведінки. Слабозорим дітям властива недостатня просторова орієнтація та збіднене емоційне життя. У дітей із порушеннями інтелектуального розвитку спостерігається недорозвиток вищих форм пам'яті, мислення, характеру. Недорозвиток особистості виявляється у примітивних реакціях, підвищеній самооцінці, негативізмі, недорозвитку волі, невротичних реакціях. Діти із розумовими вадами проявляють пасивність, інертність, підкорення сторонньому впливу, і все це - через відсутність критичного мислення. У них важко сформувати мораль, вони некритично ставляться до власної поведінки, не вміють правильно оцінити свої сили (Т. А. Власова, Г. М. Дульнєв, О. І. Дячков, І. В. Сременко, М. С. Певзнер, С. Я. Рубінштейн).

Зважаючи на вищеозначене, основними завданнями сімейного виховання $є$ :

- формування звичок позитивної поведінки;

- позитивна оцінка дитини та адекватна оцінка ії діяльності (Що зробила? Чого навчилася? Як виявила себе?);

- сприятливий психологічний клімат у сім’і $[1$, c. $56-65]$.

На психологічному рівні щодо сприйняття дитини з ООП сім'я проходить декілька етапів:

- периий - розгубленість, страх;

- другий - стан шоку трансформується в заперечення поставленого діагнозу, відмова від проходження комплексної психолого-педагогічної оцінки розвитку дитини і надання їй будь-якої психолого-педагогічної допомоги;

- третій - депресія в міру прийняття наявності в дитини ООП і правильної оцінки ситуації;

- четвертий - психічна адаптація на основі повного прийняття ООП у дитини;

- n'ятий - характеризується вмотивованою поведінкою батьків дитини з ООП, вони активно шукають допомогу для дитини, будують плани на їі майбутнє.

Існує чіткий зв'язок між сприйняттям сім'єю дитини з ООП і можливістю її соціалізації [5, с. 98].

Варто розглянути види ставлення батьків до дитини з порушеннями в розвитку (за В. Соммерсом):

- прийняття дитини з ООП - віра у власні сили і можливості дитини з ООП дає батькам внутрішню силу і підтримку;

- реакція заперечення - обмеження в дитини не приймаються та не визнаються, батьки наполягають на високій успішності діяльності дитини;

- реакція надмірного захисту, протекції, опіки у дитини формується пасивність, психологічна і соціальна незрілість;

- приховане неприйняття дитини з ООП - негативне ставлення і відраза до дитини з ООП ховаються за надмірно дбайливим вихованням;

- відкрите неприйняття дитини - для обгрунтування ворожих почуттів батьки використовують психологічний захист. Суспільство, вчителі стають винними в усіх бідах. Батьки чужою виною обгрунтовують свою ворожість і відчувають від цього полегшення.

Головне завдання вчителя - навчити батьків сприймати власну дитину з ООП як особистість.
Тому найкращі чинники, які впливають на сім'ю та дитину з ООП - це повага, похвала і заохочення дитини, розмова та спостереження за нею, наголошення на іiі сильних сторонах, вплив на дитину проханням. Що стосується роботи з батьками дітей означеної категоpiï, то вчителю необхідно налагоджувати довірливі стосунки, залучати батьків до процесу навчання і виховання та співпрацювати з командою психолого-педагогічного супроводу, розробляти разом портфоліо дитини, тобто створювати умови для соціально-педагогічної підтримки сім'ї [5, с. 99].

Утім батьки, як і будь-яка інша ланка, дотична до інклюзії, потребують відповідної підтримки і допомоги, що, безумовно, значно підвищить у цьому їхню роль. Обов'язковим є отримання батьками широкого спектра послуг, аби надати їм можливість стати компетентними захисниками прав своїх дітей для подальшого використання цих навичок у відстоюванні права дитини на рівний доступ до якісної освіти, забезпечення економічної та соціальної незалежності дітей у майбутньому.

Висновки. Отже, підсумовуючи розглянуті вище проблеми сучасності щодо організації освітнього процесу дітей з особливими освітніми потребами і педагогічні напрацювання педагога-дослідника В. О. Сухомлинського, можемо констатувати той факт, що перевірені практичним досвідом у вітчизняній школі чіткі шляхи виховання дітей на основі гуманістичних цінностей, віри в обдарованість кожної дитини, безмежного сподівання на єдність навчання і виховання мають позитивні результати завдяки спільним зусиллям із батьківською громадою.

\section{СПИСОК ВИКОРИСТАНОЇ ЛІТЕРАТУРИ}

1. Колупаєва А. А. Діти з особливими освітніми потребами та організація іх навчання. Видання доповнене та перероблене : наук.-метод. посіб. / А. А. Колупаєва, Л. О. Савчук. - К. : ВГ «АТОПОЛ», 2011. - $274 \mathrm{c}$.

2. Савчук Л. О. Особливості інклюзивного навчання та лонгітюдне дослідження В. О. Сухомлинського [Електронний pecypc]. URL: http://roippo.org. ua/activities/research/conferenc.php/1331/ (дата звернення 20.08.2019).

3. Сухомлинский В. А. «Чем лечить мозг мыслью, трудом, творчеством - или лекарствами? (Некоторые итоги 35-летнего исследования)» // Обережно: дитина! В. О. Сухомлинський про важких дітей : тематич. зб. / упор. Т. В. Філімонова ; за наук. ред. проф. О. В. Сухомлинської. - Луганськ : Луганський національний ун-тет ім. Т. Шевченка, 2008. $263 \mathrm{c}$.

4. Педагогические апокрифы. Этюды о В. А. Сухомлинском / сост., авт. вступ. ст., коммент. Ольга Васильевна Сухомлинская. - Харків : Акта, 2008. $431 \mathrm{c}$.

5. Порошенко М. А. Інклюзивна освіта : навчальний посіб. / М. А. Порошенко. - Київ : ТОВ «Агентство «Україна»», 2019. - 300 с.

Дата надходження до редакиії: 22.08.2019 р. 